\title{
Did Joseph Arch raise agricultural wages? A reply
}

\author{
George R. Boyer and Timothy J. Hatton
}

Dunbabin takes issue with us on the question of whether and by how much the agricultural workers' movement led by Joseph Arch raised agricultural wages in the early 1870s. A number of authors have speculated on what the wage effect might have been, but these speculations have rarely been based on more than a cursory examination of agricultural wage data and they have not been able to separate the effects of unionism from other factors influencing wages. Our article was the first to narrow down the range of estimates by making the best use of available data for the whole country. We used two different approaches, cross-section and time series, and in each case we were careful to use alterative specifications to ensure the results were reasonably robust. Our results suggested that unionism raised agricultural wages between 1870 and 1875 by around 3 to 6 per cent on average, a modest but perceptible effect.

In our analysis we relied on statistics for wage rates and union membership which we believe are the best available, including the union membership estimates offered some years ago by Dunbabin. Dunbabin now argues that we have put too much faith in these statistics, including his own, and that our estimates are therefore subject to 'an appreciable margin of error.' It was never our intention to produce a precise and definitive figure for the union wage effect, but rather to identify a plausible range of estimates. Dunbabin does not argue that our estimates are too high or too low and offers no alterative estimate or method of estimating. The key issue therefore is whether the data and models we use are sufficiently well grounded to support the inferences we draw from them or whether, in the absence of any alterative, we should retreat from attempting to make any inference at all. Naturally, we believe the former.

The only way to satisfy Dunbabin's misgivings is to see how far our results are vulnerable to the specific comments he makes. If more data of better quality were available we presume that he would be satisfied since he makes no criticism of the model itself-only of the reliability of the data we use to estimate it. His own statements imply that he believes that agricultural wages were determined by essentially the same forces which are embodied in our model ${ }^{1}$. Our approach then is to see how far our results change if we modify certain variables along the lines he suggests. Most of Dunbabin's criticisms apply to the data we used in our cross-sectional estimates and hence we shall concentrate on these and refer to the time series only in passing.

\section{Section I}

We turn first to the measurement of union density. It will be recalled that our calculations are based on Dunbabin's own published estimates of union membership. He raises three specific criticisms of our calculations of union density by county for 1874-the

\footnotetext{
${ }^{1}$ Dunbabin, 'Revolt of the field', p. 68; idem. Rural discontent, p. 69.
} 
year which was our main focus. First, he argues that 10 per cent of the members of the NALU Oxford district and 50 per cent of the Banbury district were outside Oxfordshire and therefore our density calculation for this county is too high. If we deduct these members then density for Oxfordshire falls from 29.0 per cent to 20.7 per cent. Secondly, he suggests that our estimate for Herefordshire is too high. In our estimate we included a share of the members in the (declining) West of England Union. If we eliminate these altogether our calculated density falls from 46.5 per cent to 36.5 per cent. Thirdly, he argues that the Kent Agricultural and General Labourers' Union contained many members who were not agricultural labourers. If we cut these numbers by half then density for Kent would decline from 23.9 per cent to 13.7 percent.

In one variant of our model we used dummy variables for 'high union density' and 'low union density' counties in 1874 . One reason for this was to avoid relying too heavily on the precise estimates for union density. We classified those counties with an estimated density of 15 per cent or more as 'high density' and those with a density greater than zero but less than 15 per cent as 'low density', and found, not surprisingly, that the strongest wage effects were in high density counties. Dunbabin's criticisms imply that only one county, Kent, crosses the boundary between high and low density and this affects only one observation in our data. Changing Kent from high to low density has little effect on the results; the new coefficient on the 'high density' dummy is 0.086 (t-statistic, 2.67) compared with our original estimate of $0.080^{2}$.

We also re-estimate the model with the modified union density variable included. In addition to the three counties mentioned above, five others are affected by the reallocation of union members: Sussex because of the same reduction applied to Kent; and Berkshire, Buckinghamshire, Warwickshire, and Northamptonshire because of the redistribution of members from NALU districts in Oxfordshire ${ }^{3}$. Altogether 17 of the 117 observations are affected by these changes. The new results are reported in column 2 of table I and can be compared with the results using the unmodified variable reported in column I. The new coefficient estimate for union density is 0.338 , slightly larger than the original estimate of 0.287 ; its statistical significance also is increased. The adjustments of union density have little effect on our results essentially because they have little effect on the ordering of counties between low and high density clusters. Further adjustments might be made to individual county densities but since there is little dispute about which counties and regions were most affected by unionism such changes would be extremely unlikely to overturn our results.

\footnotetext{
${ }^{2}$ See Boyer and Hatton, 'Joseph Arch', tab. 3, col. 4, p. 320.

${ }^{3}$ The halving of members in the Kent Agricultural and General Labourers' Union (1,000 of whom were allocated to Sussex) reduces union density for Sussex from 3.1\% to $1.5 \%$. The redistribution of members from Oxfordshire to other counties (on the basis of proximity) results in the following changes: union density in Berkshire increases from 22.5\% to 23.2\%; density in Buckinghamshire increases from $21.8 \%$ to $22.7 \%$; density in Wamickshire increases from $27.3 \%$ to $28.6 \%$; density in Northamptonshire increases from $28.1 \%$ to $32.7 \%$.

${ }^{4}$ The estimate in column I differs slightly from our original estimate ('Joseph Arch', tab. 3, col. 2, p. 320). We have corrected an error in the urban wage variable but this makes only a marginal difference to the results.
} 
Table I. The determinants of changes in the agricultural wage, 1870-1875

\begin{tabular}{|l|l|l|l|l|}
\hline & $\begin{array}{l}\text { (1) Unmodified } \\
\text { variables }\end{array}$ & $\begin{array}{l}\text { (2) Modified } \\
\text { union density }\end{array}$ & $\begin{array}{l}\text { (3) Modified } \\
\text { agricultural } \\
\text { wage }\end{array}$ & $\begin{array}{l}\text { (4) Modified } \\
\text { non-farm wage }\end{array}$ \\
\hline Constant & -0.225 & -0.182 & -0.239 & -0.283 \\
& $(1.36)$ & $(1.10)$ & $(1.47)$ & $(1.55)$ \\
\hline $\begin{array}{l}\text { Share in } \\
\text { manufacturing }\end{array}$ & 0.038 & 0.007 & 0.041 & 0.025 \\
Share in mining & 0.087 & $(0.06)$ & $(0.38)$ & $(0.22)$ \\
\hline Urban wage & $(0.48)$ & 0.105 & 0.102 & 0.092 \\
change & 0.506 & $(0.59)$ & $(0.58)$ & $(0.51)$ \\
\hline Agricultural \\
price change & $(2.13)$ & 0.517 & 0.471 & 0.743 \\
\hline Union Density & $(1.88)$ & $(2.20)$ & $(2.02)$ & $(1.86)$ \\
\hline R & 0.287 & 2.459 & 3.054 & 2.936 \\
& $(3.36)$ & $(1.59)$ & $(2.02)$ & $(1.86)$ \\
\hline RESET & 0.167 & $(3.75)$ & 0.279 & 0.284 \\
& 1.499 & 0.186 & 0.168 & $0.30)$ \\
\hline HETERO & 1.038 & 2.034 & 2.163 & 0.628 \\
\hline
\end{tabular}

Notes: The dependent variable and the variable 'Urban wage change' are defined as log Wage (1875)-log Wage (1870). $t$-statistics are in parentheses. RESET is the test for functional form using the square of the fitted values. HETERO is a test for heteroskedasticity based on the regression of squared residuals on squared fitted values. Both are chi-squared (1), critical value $=5.02$ at the $5 \%$ level.

Dunbabin also points to problems in the measurement of union membership in the late i88os and early 1890s, specifically that many of the members of the London and Southern Counties Labour League were not agricultural workers. This affects only our analysis of aggregate time series and it could account for our finding of no union wage effect during the period 1885-1903. To test this we subtracted half of the membership of the London and Southern Counties Labour League from our total union membership estimates for the years 1887 to 1894 and re-estimated the time series model using the revised union density estimates. The results were virtually identical to those we originally reported. Next, we subtracted the whole of the LSCLL membership for these years and re-estimated the model. The new coefficient estimate for union density is 0.201 ( $t$-statistic, 2.91) compared with our earlier estimate of 0.177 (t-statistic, 2.66) ${ }^{5}$. The union wage effect is slightly enhanced and the coefficients on the other variables in the equation are hardly changed ${ }^{6}$. When we enter union density variables separately for the periods 1866-84 and 1885-1903 the former coefficient is almost identical to our earlier estimate while the latter is 0.146 ( $t$-statistic, 1.09), compared with our earlier estimate of 0.098 ( $t$-statistic, 0.99$)^{7}$. In sum, adjusting the data for the late 1880 s and

\footnotetext{
${ }^{5}$ See Boyer and Hatton, 'Joseph Arch', tab. 5, col. 1, p. 327.

${ }^{6}$ The coefficient on the lagged wage ratio also rises slightly so that the estimated long run effect of a percentage point rise in unionism (see ibid., equation 2, p. 326, and p. 328) is almost unchanged, falling marginally from 0.87 to 0.86 .

${ }^{7}$ Ibid., tab. 5, col. 2, p. 327.
} 
early 1890s does not affect our conclusion that union wage effects were important in the 1870 s but not after 1885 .

\section{Section II}

Dunbabin takes issue with us on the accuracy and suitability of the wage data we use in our analysis. As our dependent variable we used agricultural wage observations for individual farms drawn from Wilson Fox's second report to the Board of Trade on agricultural labourers (1905). In our cross-section analysis we examined the change in the wage from 1870 to 1875 on the same farm. We therefore avoided explicitly comparisons across different localities, labour contracts, and types of farm ${ }^{8}$. Dunbabin suggests that the 117 farms for which we have wage data might not be representative. He points to the fact that in some counties, such as Kent, we have only one farm while in some others we have six or seven. However, the farms are reasonably evenly distributed across regions with 23 per cent in the south, 21 per cent in the south-west, 15 per cent in the east, 25 per cent in the midlands, and 16 per cent in the north. More to the point of our analysis, they are also evenly distributed across different levels of union density with 29 per cent in 'high density' counties, 31 per cent in 'low density' counties, and the remainder in counties where there was no unionism.

We used the reported weekly cash wage rate for ordinary agricultural labourers during the summer months. Dunbabin points out that there were wide variations in wages for different types of farm workers (such as shepherds, men in charge of horses or cattle etc.), and that there were variations in payments in kind and in harvest earnings as well as in months of employment. But these were variations across types of farms and workers and not typically variations over time (especially for a period as short as five or 10 years) for the same grade of labour on the same farm. Moreover, we believe that the cash wage is an appropriate measure. Most of the variations in worker remuneration over time came in the form of cash wages and the cash wage was the central focus of wage bargaining. This is not to say that unionism did not have other objectives, as Dunbabin among others has pointed out, only that in evaluating the wage outcomes of unionism it is appropriate to look at the cash wage.

Dunbabin makes the point that by focusing on the summer wage we ignore the wage paid for about two-fifths of the year, and since summer and winter wages differed in some places but not in others this might affect our estimates of the union wage effect. This is a serious point and one worth examining. We therefore calculated an alternative measure of the wage, equal to a weighted average of the June (0.6) and December (0.4) wages reported in Appendix $\mathrm{V}$ of Wilson Fox's Second Report ${ }^{9}$. This change affects 35 of our 117 observations; in the remainder the summer and winter wages were the same in 1870 and 1875 . The results obtained from reestimating the model with the new agricultural wage variable appear in column 3 of table I. The coefficient estimate for union density is 0.279 , very similar to the original estimate in column I. The coefficients on the other variables also are not materially affected by the modification of the

\footnotetext{
${ }^{8}$ We believe that this type of comparison is far superior to earlier comparisons using county level wage estimates from different surveys with differing coverage and using unknown sampling methods. This is why we avoided the use of the county level estimates reported for example by Bowley, 'Agricultural wages', not to mention the fact that comprehensive estimates are not available for the principal years of interest, 1870-5.

${ }^{9}$ The weights are those suggested by Wilson Fox in Second Report, p. 29.
} 
dependent variable. The similarity in the regression results is not surprising, given the strong correlation between summer and winter wage rates.

We turn now to Dunbabin's criticisms concerning the urban (building workers')

wage. These can be summarized in three points: (i) the wage rates used do not embody variations in working hours and in employment; (2) the carpenters' wages which we used are not necessarily representative of urban occupations as a whole (or even of the building trades); and (3) in the south, the urban alternative is based on very few towns, and particularly on London. Let us consider these points. While we could not adjust the wage rates we used for variations in hours worked, we did enter the trade union unemployment rate in our time series model to represent variations in activity in the urban sector. This variable has an important influence on the agricultural wage, as one might predict ${ }^{10}$. When unemployment was high rural workers were deterred from migrating to urban centres and hence the agricultural wage rose less than it otherwise would have. For the cross-section analysis we did not have such measures by region but this could only be a problem if regional cycles were very poorly synchronized.

Dunbabin argues that carpenters' wages are not sufficiently representative of the wages faced by rural-urban migrants. For the cross-section analysis, what matters is whether changes in carpenters' wages were well correlated with changes in urban unskilled workers' wages. Bowley regarded the rate of change of wages in the building trades as a reliable measure of the average rate of change of wages in industry ${ }^{11}$. Dunbabin criticizes our use of wage data for only three southern cities (London, Bristol, and Plymouth), and argues that 'London's pull diminished with distance'. While we agree that migration is affected by distance, it should be noted that from 1861 to 1881 London's net gain from migration was about 569,000 , compared to a net gain of 73,500 for 50 southern industrial, old, and residential cities ${ }^{12}$. London clearly was the dominant urban centre in the south and east.

The only way to see if the use of carpenters' wages or the selection of towns influences our results is to experiment with an alternative wage series which covers a wider array of urban areas. One alternative is to use wage rates for police constables. While we do not suggest that farm workers typically became police constables, constables' wages did reflect local labor: market conditions and they are available for every county. We have grouped these into regional averages using 1871 county population weights. In column 4 of table I we report the results obtained by re-estimating the model using this alternative measure of the urban (more correctly non-farm) wage. The coefficient on this wage index is larger than that for the carpenters' wage, and its $t$-statistic is lower, but the other coefficients are little changed. In particular the coefficient on union density is very similar, at 0.284 compared with 0.287 in column I. To repeat: we do not wish to argue that the police constables' wage is the appropriate alterative wage, only that the effect of union density is not very sensitive to the use of a completely different non-farm wage in the model.

\footnotetext{
${ }^{10}$ See Boyer and Hatton, 'Joseph Arch', tab. 5, p. 327.

${ }^{11}$ Bowley, Wages, pp. 59, 63. Similarly, Hunt, 'Regional inequality', p. 962, maintains that carpenters' wages are 'a reasonably reliable guide to town wages.'

${ }^{12}$ Cairncross, 'Internal migration', p. 83.
} 


\section{Section III}

We have attempted to test the robustness of our results concerning the effect of ritual unionism in the 1870 s by using alternative definitions of the variables suggested by Dunbabin's comments. The model easily passes these tests and the results suggest that only the most dramatic (and implausible) changes could seriously undermine our main findings. We are grateful to Dunbabin for his scholarly criticism of our article and for providing us with the opportunity to demonstrate the robustness of our results.

It is worth putting these results in a somewhat broader perspective. Our crosssection estimate suggests that unionism raised average agricultural wages by about 3 per cent in 1875. Although this increase may seem modest, the union wage effect' (the coefficient on union density) is large at about 28 per cent ${ }^{13}$. These results may be compared with our recent estimates of the union wage effect for a cross-section of 956 individual male workers in eight industries in $1890^{14}$. We obtained lower bound estimates which suggest a union wage effect of 16 per cent for unskilled workers, 12 per cent for semi-skilled workers, and 15 per cent for skilled workers, although upper bound estimates suggest that the wage effect might have been as much as twice these levels. Our estimates are larger than those typically found in studies of postwar data which average 8 per cent $^{15}$.

On the face of it unionism appears to have had a more powerful influence on wages in the late nineteenth century than it has now. However, our estimates for agricultural workers in the 1870s and for industrial workers in 1890 are measured during periods of rapid growth in trade unionism. Phelps Brown argued that newly formed trade unions often had an initial shock effect on wage rates, and Pollard maintained that 'unions were particularly effective on first appearance in occupations in which long-standing inferiority had created an almost permanent social gap', such as agriculture ${ }^{16}$. These initial wage gains proved to be 'difficult, if not impossible, to hold' in the face of employers' inevitable counter-offensives $^{17}$. Our evidence for agriculture suggests that union wage effects were weak after the 1870s. Thus we might expect that under more normal conditions the union wage effect was more modest and perhaps similar to that observed in postwar studies. But we shall have to await the results of further quantitative studies along these lines before we can be sure.

Cornell University

University of Essex

\footnotetext{
${ }^{13}$ The 'union wage effect' is normally measured as the percentage increase in an individual's wage associated with moving from non-union to union status. The equivalent at the county level would be the predicted percentage average increase associated with moving from zero to $100 \%$ union density. Between 1870 and 1874 union density (weighted by the county composition of farms in our sample) rose from zero to io. $8 \%$ and hence the effect on the average wage is $0.108 * 0.28=0.03$, or $3 \%$.

${ }^{14}$ Hatton, Boyer, and Bailey, 'Union wage effect.'

${ }^{15}$ Booth, Economics of the trade union, pp. 165-7.

${ }^{16}$ Phelps Brown, Economics of labor, pp. 180-1; Pollard, 'Trade unions', p. no.

${ }^{17}$ Pollard, 'Trade unions', p.110
} 


\section{Footnote references}

Board of Trade, Labour Department, 'Confidential' print of Rates of Wages and Hours of Labour in Various Industries in the United Kingdom for a Series of Years (1908; Dept of Employment Library,London, 331-2 (i)).

Booth, A. L., The economics of the trade union (Cambridge, 1995).

Bowley, A. L., 'The statistics of wages in the United Kingdom during the last hundred years, i; agricultural wages', J.R.S.S., LXI (1898), pp. 702-22.

Bowley, A. L., Wages in the United Kingdom in the nineteenth century (Cambridge, 1900).

Boyer, G. R. and Hatton, T. J., 'Did Joseph Arch raise agricultural wages?: rural trade unions and the labour market in late nineteent-century England', Econ. Hist. Rev., XLVII (1994), pp. 310-34.

Cairncross, A. K., 'Internal migration in Victorian England', Man. School, 17 (1949), pp. 67-87.

Dunbabin, J. P., 'The "revolt of the field": the agricultural labourers' movement in the 1870s', P.\& P., 26 (1963), pp. 68-97.

Dunbabin, J. P., Rural discontent in nineteenth-century Britain (New York, 1974).

Dunbabin, J. P., 'Can we tell whether Arch raised wages?', Econ. Hist. Rev., XLIX (1996), pp. 000-000

Hatton, T. J., Boyer, G. R., and Bailey, R. E., 'The union wage effect in late nineteenthcentury Britain', Económica, 61 (1994), pp. 435-56-

Hunt, E. H., 'Industrialization and regional inequality: wages in Britain, 1760-1914', J. Econ. Hist., XLVi (1986), pp. 935-66.

Phelps Brown, E. H., The economics of labor (New Haven, 1962).

Pollard, S., 'Trade unions and the labour market, 1870-1914', York. Bull. Econ. Soc. Res., 12 (1965), pp. 98-112.

\section{Official publications}

Board of Trade, Second Report by Mr Wilson Fox on the Wages, Earnings, and Conditions of Employment of Agricultural Labourers in the United Kingdom (P.P. 1905, xcvii). 